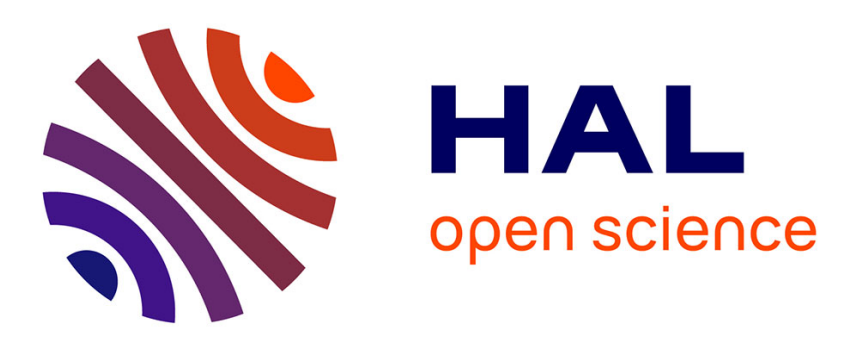

\title{
First results from the Sweeping Langmuir Probe (SLP) instrument on board PICASSO
}

\author{
Sylvain Ranvier, Johan de Keyser, Jean-Pierre Lebreton
}

\section{To cite this version:}

Sylvain Ranvier, Johan de Keyser, Jean-Pierre Lebreton. First results from the Sweeping Langmuir Probe (SLP) instrument on board PICASSO. vEGU21, 2021, Online, France. 10.5194/egusphereegu21-9915 . insu-03559303

\section{HAL Id: insu-03559303 https://hal-insu.archives-ouvertes.fr/insu-03559303}

Submitted on 7 Feb 2022

HAL is a multi-disciplinary open access archive for the deposit and dissemination of scientific research documents, whether they are published or not. The documents may come from teaching and research institutions in France or abroad, or from public or private research centers.
L'archive ouverte pluridisciplinaire HAL, est destinée au dépôt et à la diffusion de documents scientifiques de niveau recherche, publiés ou non, émanant des établissements d'enseignement et de recherche français ou étrangers, des laboratoires publics ou privés.

\section{(c)(1)}

Distributed under a Creative Commons Attribution| 4.0 International License 


\section{EGU21-9915}

https://doi.org/10.5194/egusphere-egu21-9915

EGU General Assembly 2021

(c) Author(s) 2022. This work is distributed under

the Creative Commons Attribution 4.0 License.

\section{First results from the Sweeping Langmuir Probe (SLP) instrument on board PICASSO}

Sylvain Ranvier ${ }^{1}$, Johan De Keyser ${ }^{1}$, and Jean-Pierre Lebreton ${ }^{2,3}$

${ }^{1}$ Royal Belgian Institute for Space Aeronomy (BIRA-IASB), Brussels, Belgium (sylvain.ranvier@aeronomie.be)

${ }^{2}$ Laboratoire de Physique et Chimie de l'Environnement et de l'Espace (LPC2E), Orléans, France

${ }^{3}$ Laboratoire d'Etudes Spatiales et d'Instrumentation en Astrophysique (LESIA), Meudon, France

The Sweeping Langmuir Probe (SLP) instrument on board the Pico-Satellite for Atmospheric and Space Science Observations (PICASSO) has been developed at the Royal Belgian Institute for Space Aeronomy. PICASSO, an ESA in-orbit demonstrator launched in September 2020, is a triple unit CubeSat orbiting at about $540 \mathrm{~km}$ altitude with 97 degrees inclination. The SLP instrument includes four independent cylindrical probes that are used to measure the plasma density and electron temperature as well as the floating potential of the spacecraft. Along the orbit of PICASSO the plasma density is expected to fluctuate over a wide range, from about $1 \mathrm{e} 8 / \mathrm{m}^{3}$ at high latitude up to more than $1 \mathrm{e} 12 / \mathrm{m}^{3}$ at low/mid latitude. SLP can measure plasma density from $1 \mathrm{e} 8 / \mathrm{m}^{3}$ to $1 \mathrm{e} 13 / \mathrm{m}^{3}$. The electron temperature is expected to lie between approximately $1000 \mathrm{~K}$ and $10.000 \mathrm{~K}$. Given the high inclination of the orbit, SLP will allow a global monitoring of the ionosphere. Using the traditional sweeping mode, the maximum spatial resolution is of the order of a few hundred meters for the plasma density, electron temperature and spacecraft potential. With the fixed-bias mode, the electron density can be measured with a spatial resolution of about $1.5 \mathrm{~m}$. The main goals are to study the ionosphere-plasmasphere coupling, the subauroral ionosphere and corresponding magnetospheric features together with auroral structures and polar caps, by combining SLP data with other complementary data sources (space- or ground-based instruments). The first results from SLP will be presented. 